\title{
Partial Agonism of Taurine at Gamma-Containing Native and Recombinant $\mathrm{GABA}_{\mathrm{A}}$ Receptors
}

\author{
Olaf Kletke ${ }^{1,2}$, Guenter Gisselmann ${ }^{1}$, Andrea May ${ }^{2}$, Hanns Hatt ${ }^{1}$, Olga A. Sergeeva ${ }^{2 *}$
}

1 Department of Cell Physiology of the Ruhr-University, Bochum, Germany, 2 Department of Neurophysiology, Medical Faculty of Heinrich-Heine University, Düsseldorf, Germany

\begin{abstract}
Taurine is a semi-essential sulfonic acid found at high concentrations in plasma and mammalian tissues which regulates osmolarity, ion channel activity and glucose homeostasis. The structural requirements of $G A B A_{A}-$ receptors $_{\left(G A B A_{A} R\right)}$ gated by taurine are not yet known. We determined taurine potency and efficacy relative to GABA at different types of recombinant $G A B A_{A} R$ occurring in central histaminergic neurons of the mouse hypothalamic tuberomamillary nucleus (TMN) which controls arousal. At binary $\alpha_{1 / 2} \beta_{1 / 3}$ receptors taurine was as efficient as GABA, whereas incorporation of the $\gamma_{1 / 2}$ subunit reduced taurine efficacy to $60-90 \%$ of GABA. The mutation $\gamma_{2 F 771}$, which abolishes zolpidem potentiation, significantly reduced taurine efficacy at recombinant and native receptors compared to the wild type controls. As taurine was a full- or super- agonist at recombinant $\alpha_{x} \beta_{1} \delta-G A B A_{A} R$, we generated a chimeric $\gamma_{2}$ subunit carrying the $\delta$ subunit motif around F77 (MTVFLH). At $\alpha_{1 / 2} \beta_{1} \gamma_{2 \text { (MTVFLH) }}$ receptors taurine became a super-agonist, similar to $\delta$-containing ternary receptors, but remained a partial agonist at $\beta_{3}$-containing receptors. In conclusion, using site-directed mutagenesis we found structural determinants of taurine's partial agonism at $\gamma$-containing $G_{A B A}$ receptors. Our study sheds new light on the $\beta_{1}$ subunit conferring the widest range of taurine-efficacies modifying $G A B A_{A} R$ function under (patho)physiological conditions.
\end{abstract}

Citation: Kletke O, Gisselmann G, May A, Hatt H, Sergeeva OA (2013) Partial Agonism of Taurine at Gamma-Containing Native and Recombinant GABA Receptors. PLoS ONE 8(4): e61733. doi:10.1371/journal.pone.0061733

Editor: Pascale CHAVIS, INSERM U901, France

Received November 1, 2012; Accepted March 13, 2013; Published April 30, 2013

Copyright: (c) 2013 Kletke et al. This is an open-access article distributed under the terms of the Creative Commons Attribution License, which permits unrestricted use, distribution, and reproduction in any medium, provided the original author and source are credited.

Funding: Supported by Deutsche Forschungsgemeinschaft SFB 575/TP C8 and a Heisenberg stipend to OAS (SE 1767). URL: http://www.dfg.de. The funders had no role in study design, data collection and analysis, decision to publish, or preparation of the manuscript.

Competing Interests: The authors have declared that no competing interests exist.

*E-mail: olga.sergeeva@uni-duesseldorf.de

\section{Introduction}

Taurine (2-aminoethane sulfonic acid) is very abundant in plasma and mammalian tissues including brain, where it regulates osmolarity, ion channel activity, neuronal growth and metabolism [1-4]. It remains controversial whether taurine can be called "neurotransmitter": some but not other studies reported accumulation of taurine in the synaptic vesicles [5;6] and action potentialdependent release [7]. Taurine concentrations range from 3 to 9 $\mathrm{mM}$ in different species and brain regions and may reach $20 \mathrm{mM}$ or higher in intracellular compartments [8]. Intracellular concentrations of taurine in the brain are about 400 times higher then extracellular [9] due to the high-affinity uptake system [10]. Taurine release from different CNS cells is observed under pathophysiological conditions such as hypoosmotic stress, ischemia or acute hyperammonemia, where its interaction with the receptors for inhibitory neurotransmitters GABA and glycine plays a neuroprotective role [8]. In many brain areas taurine in concentrations below $1 \mathrm{mM}$ activates glycine but not $\mathrm{GABA}_{\mathrm{A}}$ receptors, except for the ventrobasal thalamus, where it activates $\alpha_{4} \beta_{2} \delta$ GABA $_{\mathrm{A}}$ R-type at physiological concentrations $(10-100 \mu \mathrm{M})$ [11]. Mice deficient in taurine show impaired GABAergic inhibition in the striatum [12], indicating yet unrecognised role of taurine for the proper GABAergic signalling. If molecular structure of taurine binding site at different glycine receptor types are known [13;14], taurine binding site at $\mathrm{GABA}_{\mathrm{A}}$ receptor was not yet systematically analysed. Efficacy and potency of taurine is so far only known for a few subunit combinations. Taurine acts as a full agonist at $\alpha_{1} \beta_{3}$ and a partial agonist at $\alpha_{1} \beta_{3} \gamma_{2}$ receptors [15]; at $\alpha_{4} \beta_{2} \delta$ receptors taurine elicits even greater currents than GABA [11] and at $\alpha_{6} \beta_{2} \delta \mathrm{GABA}_{\mathrm{A}} \mathrm{R}$ taurine is a partial agonist, with variable $\mathrm{EC}_{50} \mathrm{~s}$ depending on the expression level [16]. The molecular mechanism that determines the efficacy of taurine at GABA $_{\mathrm{A}} \mathrm{Rs}$ is unknown. A comparative analysis of taurine gating of $\mathrm{GABA}_{\mathrm{A}} \mathrm{R}$ containing different $\beta$ subunits was not yet performed. $\mathrm{GABA}_{\mathrm{A}} \mathrm{Rs}$ are heteropentameres composed of five subunits. A multitude of subunits can assemble to functional receptors $\left(\alpha_{1-6}\right.$, $\beta_{1-3}, \gamma_{1-3}, \delta-, \varepsilon-, \theta-, \pi$-and $\left.\rho_{1-3}\right)$ [17]. According to the current view GABA $_{A}$ Rs are composed of two $\alpha$, two $\beta$ and one $\gamma$ (or $\delta$ ) subunits aligned $\gamma-\beta-\alpha-\beta-\alpha$ counter-clockwise when viewed from the synaptic cleft [18]. Mutational analysis studies demonstrated that the agonist binding site is located at the $\alpha / \beta$ interface and the benzodiazepine binding site at the $\alpha / \gamma$ interface $[17 ; 19 ; 20]$. The binding sites for the partial agonists at $\mathrm{GABA}_{\mathrm{A}} \mathrm{R}$ are unclear [21]. The largest population of $\mathrm{GABA}_{\mathrm{A}} \mathrm{Rs}_{\mathrm{s}}$ in the rat brain has a subunit composition of $\alpha_{1} \beta_{2} \gamma_{2}$, whereas $\alpha_{2} \beta_{3} \gamma_{2}$ and $\alpha_{3} \beta \gamma_{2 / 3}$ together constitute the next most prevalent subtypes [22;23]. Several subunit combinations such as $\alpha_{5} \beta_{3} \gamma_{2}$ [22] and $\alpha_{4 / 6} \beta_{2 / 3} \delta$ [23;24] are found exclusively extrasynaptically, with the former type expressed in the hypothalamus. Histaminergic neurons from the tuberomamillary nucleus (TMN) of the hypothalamus were selected for the present study as functional and structural features of their $\mathrm{GABA}_{\mathrm{A}}$ receptors were previously characterised with the 
$\alpha 1, \alpha 2, \alpha 5, \beta 1, \beta 3, \gamma 1, \gamma 2, \varepsilon$, but not $\delta$ subunit- transcripts being regularly detected [25-28]. We compare now the taurinesensitivity of native $\mathrm{GABA}_{\mathrm{A}} \mathrm{R}$ versus selected $\mathrm{GABA}_{\mathrm{A}} \mathrm{R}$ compositions recombinantly expressed in Xenopus oocytes. As we aimed to compare properties of recombinant $\mathrm{GABA}_{\mathrm{A}} \mathrm{R}$ with the native receptors expressed in hypothalamic neurons we restricted the number of investigated subunits and receptor types to those present in TMN neurons [27;28]. We report that incorporation of the $\gamma$ subunit reduces taurine efficacy. With the help of sitedirected mutagenesis we describe structural determinants for the partial agonism of taurine at $\gamma$-containing $\mathrm{GABA}_{\mathrm{A}} \mathrm{Rs}$.

\section{Materials and Methods}

\section{Electrophysiology in Native Neurons}

Experiments were conducted according to the Animal Protection Law of the Federal Republic of Germany (Tierschutzgesetz BGBI.I,S.1206, revision 2006) and European Communities Council directive regarding care and use of animals for experimental procedures (86/609/EEC). Approval by the Ethics Committee for this kind of experiment is not necessary in accordance with the Animal Protection Law of the Federal Republic of Germany (§ 8 Abs.1 Tierschutzgesetz). All efforts were made to minimize the number of animals and their suffering. Brain tissue was removed from mice after decapitation by appropriately trained staff with approval of LANUV NRW (Landesamt für Umwelt, Natur und Verbraucherschutz Nordrhein Westfalen, Düsseldorf), permission number 058/91.

Five to eight week old male mice carrying a point mutation on $\mathrm{GABA}_{\mathrm{A}} \mathrm{R} \gamma_{2}$ subunit $\left(\gamma_{2 \text { F77I }}\right)$ further referred as KI (knock-in) mice and their wild type littermates were generated and genotyped as described previously [29]. Slice preparation, isolation of histaminergic neurons with the help of papain, whole-cell patch-clamp recordings in voltage clamp mode, fast drug application and single cell RT-PCR procedures was done as previously described [26;27]. Briefly, sterile patch electrodes were filled with the following solution: $140 \mathrm{mM} \mathrm{KCl}, 2 \mathrm{mM} \mathrm{MgCl} 2,0.5 \mathrm{mM} \mathrm{CaCl}_{2}, 5$ $\mathrm{mM}$ EGTA, and $10 \mathrm{mM}$ HEPES/KOH (pH 7.2). After establishment of the whole-cell configuration $(\mathrm{Vh}=-50 \mathrm{mV})$, an acutely isolated cell was lifted into the major chute of the application system, where it was continuously perfused with the sterile control bath solution. The substances were applied through a glass capillary $0.08 \mathrm{~mm}$ in diameter. All solutions flowed continuously, gravity-driven, at the same speed and lateral movements of the capillaries exposed a cell either to control- or test-solutions. The kinetics of solution exchange at the open electrode tip were characterized by an exponential rise time constant of $7 \mathrm{~ms}$, whereas the maximal GABA-evoked responses reached their maximum up to 2 times slower; thus peak responses represented the sum of activation, desensitization and delay of solution exchange around the large $(15-25 \mu \mathrm{m})$ neurons (see Schubring et al [30]). For the comparison of apparent desensitization kinetics between zinc sensitive and zinc resistant neurons, only cells with a rise time constant below $10 \mathrm{~ms}$ were considered. Experiments were conducted and analyzed with commercially available software (TIDA for Windows, HEKA, Lambrecht, Germany). Fitting of concentration - response data points was done as previously described [25;26]. Post-hoc identification of recorded TMN neurons and $\mathrm{GABA}_{\mathrm{A}} \mathrm{R}$ analysis was done with single cell RT-PCR according to the previously published protocols [27;28]. Real-time RT - PCR was used for the semiquantitative analysis of $\gamma_{2}$ subunit expression in TMN (relative to the $\beta$-actin endogenous control according to the

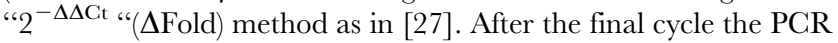

were subjected to a heat dissociation protocol (PE Biosystems 5700 software). Each PCR product showed a single peak in the denaturation curve. Standard curves were obtained with the sequential dilution of one cDNA sample (from KI mouse \#1). From these curves the linear regression coefficient $(r=-0.99)$ and efficiency $(\mathrm{E}=1.8)$ for the $\beta$-actin and $\gamma_{2}$ subunit - cDNA amplification $(\mathrm{r}=-0.98, \quad \mathrm{E}=1.9)$ were calculated, where $\mathrm{E}=10^{[-1 / \text { slope }]}$. Expression levels of the $\gamma_{2}$-subunit in each sample are normalized to the sample with minimal expression (for this sample: $\left.\Delta \Delta \mathrm{C}=0,2^{-\Delta \Delta \mathrm{Ct}=} 1\right)$. The following primers were used: up: $5^{\prime}$-tat gtD aac agc att ggW ccW gt $-3^{\prime}$ and lo: $5^{\prime}$-acc atc att cca aat tct cag cat- $3^{\prime}$. The size of the PCR product (234 b.p.) was verified by electrophoresis in $2 \%$ agarose gel, whereas its identity with the known mouse $\gamma_{2}$-subunit cDNA (M86572, Genbank) was confirmed by sequencing.

\section{Expression of Recombinant $\mathrm{GABA}_{\mathrm{A}}$ Receptors and Electrophysiology in Xenopus Oocytes}

$\mathrm{GABA}_{\mathrm{A}} \mathrm{R}$ subunit $\mathrm{cDNAs}$ were obtained as follows: rat $\alpha_{1}$ and $\beta_{1}$ cDNAs were prepared using standard molecular biology procedures. Mouse $\gamma_{2 L}, \alpha_{2}$, and human $\beta_{3}$ and $\delta$ cDNA were obtained from RZPD (Berlin, Germany). Chimeric $\gamma_{2(\delta}$ 74-79) was generated using overlap extension PCR [31] with the following primer pairs for the exchanged area: $\mathrm{fw}-\gamma_{2(\delta}{ }_{74-79)}$ ' 5 -atg gaa tat aca atg acg gtg ttc ctg cac cag agc tgg cgg gac aga cgt ttg aaa ttt aac- $3^{\prime}$ and rev- $\gamma_{2(\delta}$ 74-79) '5-gtt aaa ttt caa acg tct gtc ccg cca gct ctg gtg cag gaa cac cgt cat tgt ata ttc cat-3'. All cDNAs were subcloned into pSGEM (courtesy of M. Hollmann, Bochum, Germany). Plasmids were linearized with PacI restriction endonuclease and corresponding cRNA was synthesized using the AmpliCap T7 high-yield message marker kit (Epicentre, Madison, $\mathrm{WI}$ ), following the manufacturers protocol. 5 to $15 \mathrm{ng}$ of the mixture of cRNAs with a ratio of 10:1:10 for $\alpha \beta \gamma / \delta$ was injected into every oocyte to prevent subpopulations of $\beta$ homomultimeric $\mathrm{GABA}_{\mathrm{A}} \mathrm{R}$ [32]. Two to six days after injection of cRNA, oocytes were screened for receptor expression by two-electrode voltageclamp recording. Electrodes were made using a Kopf vertical micropipette puller and filled with $3 \mathrm{M}$ potassium chloride, giving resistances of $0.1-0.5 \mathrm{M} \Omega$. Eggs were placed in an oocyte chamber and superfused with Frog-Ringer's solution (115 mM NaCl, 2.5 $\mathrm{mM} \mathrm{KCl}, 1.8 \mathrm{mM} \mathrm{CaCl}_{2}, 10 \mathrm{mM}$ Hepes, $\mathrm{pH}$ 7.2). Current signals were recorded with a two-electrode voltage - clamp amplifier (TURBO TEC-03, npi, Tamm, Germany) and pCLAMP software (Axon Instruments, Union City, CA) or CellWorks (npi, Tamm, Germany) depending on the setup used. The membrane potential was clamped at -40 to $-60 \mathrm{mV}$. All experiments were performed at room temperature. Complete concentration - response curves for GABA and taurine were recorded on the same oocyte. These agonists of $\mathrm{GABA}_{\mathrm{A}} \mathrm{R}$ were dissolved in Frog-Ringer and applied in a volume of $200 \mu \mathrm{l}$ into the entrance tube of the recording chamber, totally exchanging the bath solution within a second. Currents were analyzed using pCLAMP 10 software. Dataset was processed in Excel (Microsoft Corporation, Redmond, WA). Curve fitting by the 3 parameter Hill equation and statistics $(\mathrm{t}$ test) was done using SigmaPlot V8.0 (Systat Software, San Jose, CA). Taurine efficacy was determined by the maximum of the taurine concentration - response curve calculated by the 3 parameter Hill equation in relation to the maximum current of the GABA concentration - response curve. Proper $\gamma$ subunit integration into the $\mathrm{GABA}_{\mathrm{A}} \mathrm{R}$ was analysed using zinc. Ternary $\alpha \beta \gamma \mathrm{GABA}_{\mathrm{A}} \mathrm{Rs}$ are insensitive to low micromolar concentrations of zinc, whereas binary $\alpha \beta$ receptors are inhibited by those concentrations [33] (Figure S1). Delta $(\delta)$ - containing $\mathrm{GABA}_{\mathrm{A}} \mathrm{R}$ have intermediate zinc sensitivities [34], therefore our criterion for 
$\delta$ subunit integration was the modulation of GABA - evoked currents by tracazolate (Figure S2). In accordance with Thompson et al. [35] we found that tracazolate potentiates ternary $\delta$ containing $\mathrm{GABA}_{\mathrm{A}} \mathrm{R}$ to a larger extent than the corresponding binary $\alpha_{\mathrm{x}} \beta_{\mathrm{x}}$ receptors.

\section{Drugs and Statistical Analysis}

Gabazine (SR 95531) and tracazolate were obtained from Tocris-Biotrend (Köln, Germany). All other chemicals were obtained from Sigma-Aldrich (Taufkirchen, Germany). Drugs were diluted and stored as recommended. Statistical analysis was performed with the non - parametrical Mann - Whitney U-test if not indicated otherwise. Significance level was set at $p<0.05$. Data are presented as mean \pm standard error of the mean (SEM).

\section{Results}

\section{Taurine Efficacy and Potency at $\mathrm{GABA}_{\mathrm{A}}$ Receptors Composed of $\alpha$ and $\beta$ Subunits}

In accordance with the study performed in HEK 293 cells by Dominguez-Perrot et al. [15] recombinant GABA $_{\mathrm{A}} \mathrm{R}$ composed of $\alpha_{1}$ - and $\beta_{3}$-subunits in our study responded to GABA and to taurine with maximal currents of similar amplitude (Table 1). At receptors containing the $\beta_{1}$-subunit taurine demonstrated superagonism, eliciting maximal responses nearly two times larger than the maximal GABA responses (Table 1). When the $\alpha_{1}$-subunit was replaced by the $\alpha_{2}$-subunit GABA and taurine potencies were reduced at $\beta_{1}$-containing receptors whereas taurine potency at $\beta_{3}$ containing receptors was not affected. Taurine efficacy was independent of the $\alpha$-subunit type and was determined by the $\beta$ subunit type.

\section{Presence of $\gamma_{2}$-subunit Reduces Taurine Efficacy}

When co-assembled with the $\alpha$ - and $\beta$-subunits the $\gamma_{2 L}$ subunit negatively affected taurine efficacy in all receptor types. At $\alpha_{2} \beta_{3} \gamma_{2 L}$ taurine efficacy (0.87) showed the slightest but significant deviation in efficacy reduction compared to the binary $\alpha_{2} \beta_{3}$ receptors (Table 1, Fig. 1). After integration of the $\gamma_{2 L}$ or $\gamma_{1}$ subunit into $\beta_{1^{-}}$ containing receptors, the efficacy of taurine was reduced to about $1 / 3$ of the binary $\alpha_{x} \beta_{1}$ receptor and taurine could be called a "partial agonist". Previous studies have shown that the putative assembly signals, the residues determining selective co-assemblies of $\alpha-\beta$ or $\alpha-\gamma_{2}$, in $\mathrm{GABA}_{\mathrm{A}} \mathrm{Rs}$ [36] as well as in nicotinic acetylcholine receptors [37], are adjacent to, or identical to the residues that actually form the ligand-binding site. Thus, the $\alpha_{1}$ residues $56-67$, in particular glutamine $67\left(\alpha_{1067}\right)$, are important for the assembly with the $\beta_{3}$ subunit and are involved in the formation of the low affinity GABA-binding site [36;38]. The $\gamma_{2} \mathrm{~A}$ assembly signal (MEYTIDIFFAQTW) [36] which interacts with the $\alpha$ subunit includes phenylalanine at position 77 (F77). This residue plays an important role for the zolpidem modulation of $\gamma_{2^{-}}$ containing $\mathrm{GABA}_{\mathrm{A}} \mathrm{R}$ [39].

\section{Role of Zolpidem Binding Site for the $\mathrm{GABA}_{\mathrm{A}} \mathrm{R}$ Gating by Taurine}

The mutation of phenylalanine to isoleucine at position 77 of $\mathrm{GABA}_{\mathrm{A}} \mathrm{R} \gamma_{2}$ subunit $\left(\gamma_{2 \mathrm{~F} 77 \mathrm{I}}\right)$ leads to the loss of zolpidemmodulation of GABA-responses in recombinant and native receptors [29;39]. This is the only residue, which is different between the $\gamma_{2}$ and the $\gamma_{1}$ subunit within the putative assembly signal $\gamma_{2} \mathrm{~A}$ (see above). As taurine was significantly less efficient at $\alpha_{2} \beta_{3} \gamma_{1}$ - than at $\alpha_{2} \beta_{3} \gamma_{2^{-}}$receptors (Table 1) we generated a mutated $\gamma_{2 \text { F77I }}$ subunit using overlap extension PCR techniques
Table 1. GABA- and taurine- gating of different $G A B A_{A}$ receptor types recombinantly expressed in Xenopus oocytes.

\begin{tabular}{|c|c|c|c|c|c|c|}
\hline & \multicolumn{2}{|l|}{ GABA } & \multicolumn{3}{|l|}{ Taurine } & \multirow[b]{2}{*}{$\mathbf{n}$} \\
\hline & nHill & $E C_{50}[\mu \mathrm{M}]$ & Imax & nHill & $\mathrm{EC}_{50}[\mathrm{mM}]$ & \\
\hline$\alpha_{1} \beta_{1}$ & $1.82 \pm 0.13$ & $38.0 \pm 0.8$ & $2.26 \pm 0.27$ & $0.71 \pm 0.07$ & $759.3 \pm 18.8$ & 4 \\
\hline$\alpha_{1} \beta_{1} \delta$ & $1.85 \pm 0.10$ & $8.5 \pm 1.8$ & $2.75 \pm 0.05^{*}$ & $0.60 \pm 0.02$ & $162.6 \pm 33.4^{*}$ & 5 \\
\hline$\alpha_{1} \beta_{1} \gamma_{2}$ & $1.82 \pm 0.16$ & $10.0 \pm 1.1$ & $0.81 \pm 0.03^{*}$ & $1.20 \pm 0.04^{*}$ & * $17.6 \pm 2.18$ & 4 \\
\hline$\alpha_{1} \beta_{1} \gamma_{2(874-79)}$ & $1.38 \pm 0.10^{*}$ & $* 13.2 \pm 1.6^{*}$ & $2.7 \pm 0.30^{*}$ & $0.48 \pm 0.02^{*}$ & * $433.4 \pm 94.8^{*}$ & 7 \\
\hline$\alpha_{1} \beta_{1} \gamma_{2 F 771}$ & $1.60 \pm 0.13$ & $36.2 \pm 6.7^{*}$ & $0.53 \pm 0.10^{*}$ & $0.91 \pm 0.09$ & $68.6 \pm 13.9$ & 5 \\
\hline$\alpha_{1} \beta_{3}$ & $1.92 \pm 0.21$ & $17.8 \pm 0.8$ & $1.06 \pm 0.06$ & $0.96 \pm 0.09$ & $926.1 \pm 9.5$ & 5 \\
\hline$\alpha_{1} \beta_{3} \delta$ & $1.44 \pm 0.09 *$ & * $21.4 \pm 8.1$ & $0.74 \pm 0.04^{*}$ & $1.09 \pm 0.08$ & $45.3 \pm 10.5$ & 6 \\
\hline$\alpha_{1} \beta_{3} \gamma_{2}$ & $1.68 \pm 0.15$ & $16.7 \pm 2.3^{*}$ & $0.63 \pm 0.09^{*}$ & $1.30 \pm 0.13^{*}$ & * $86.3 \pm 16.5^{*}$ & . \\
\hline$\alpha_{1} \beta_{3} \gamma_{2(874-79)}$ & $1.34 \pm 0.03^{*}$ & & $48.4 \pm 14.2^{* *}$ & $0.44 \pm 0.07^{*}$ & $* 0.94 \pm 0.09$ & \\
\hline $92.9 \pm 16.3^{*}$ & 5 & & & & & \\
\hline$\alpha_{1} \beta_{3} \gamma_{2}$ F771 & $1.58 \pm 0.13$ & $66.4 \pm 86.3^{*}$ & $* 0.2$ & n.p. & n.p. & 5 \\
\hline$\alpha_{2} \beta_{1}$ & $1.86 \pm 0.19$ & $918.0 \pm 2.1$ & $1.80 \pm 0.14$ & $1.12 \pm 0.16$ & $681.8 \pm 24.9$ & 7 \\
\hline$\alpha_{2} \beta_{1} \delta$ & $1.72 \pm 0.11$ & $19.1 \pm 1.4$ & $1.94 \pm 0.11$ & $1.02 \pm 0.09$ & $67.8 \pm 15.9$ & 6 \\
\hline$\alpha_{2} \beta_{1} \gamma_{1}$ & $1.35 \pm 0.10^{*}$ & $* 87.1 \pm 7.1 *$ & $0.64 \pm 0.03^{*}$ & $1.22 \pm 0.30$ & $107.2 \pm 25.8$ & 4 \\
\hline$\alpha_{2} \beta_{1} \gamma_{2}$ & $1.37 \pm 0.08^{*}$ & * $71.2 \pm 12.5^{*}$ & $* 0.65 \pm 0.05^{* *}$ & $1.06 \pm 0.06$ & $120.3 \pm 26.0$ & 5 \\
\hline$\alpha_{2} \beta_{1} \gamma_{2(874-79)}$ & $1.88 \pm 0.04$ & $15.1 \pm 0.4$ & $1.43 \pm 0.06$ & $0.98 \pm 0.07$ & $40.5 \pm 6.9$ & 7 \\
\hline$\alpha_{2} \beta_{1} \gamma_{2}$ F771 & $1.68 \pm 0.06$ & $58.2 \pm 3.9^{*}$ & $0.49 \pm 0.02^{* *}$ & $1.29 \pm 0.02$ & $76.1 \pm 3.9$ & 5 \\
\hline$\alpha_{2} \beta_{3}$ & $1.48 \pm 0.21$ & $112.9 \pm 6.5$ & $1.03 \pm 0.04$ & $1.07 \pm 0.08$ & $824.5 \pm 11.2$ & 4 \\
\hline$\alpha_{2} \beta_{3} \delta$ & $1.47 \pm 0.06$ & $13.5 \pm 1.0$ & $1.10 \pm 0.03$ & $1.29 \pm 0.03^{*}$ & * $35.4 \pm 2.0$ & 7 \\
\hline$\alpha_{2} \beta_{3} \gamma_{1}$ & $1.45 \pm 0.05$ & $93.8 \pm 12.2^{*}$ & $* 0.44 \pm 0.04$ & n.p. & n.p. & 4 \\
\hline$\alpha_{2} \beta_{3} \gamma_{2}$ & $2.12 \pm 0.01^{*}$ & * $18.7 \pm 0.9$ & $0.87 \pm 0.03^{*}$ & $1.14 \pm 0.11$ & $51.2 \pm 19.8$ & 4 \\
\hline$\alpha_{2} \beta_{3} \gamma_{2(874-79)}$ & $1.47 \pm 0.05$ & $42.8 \pm 5.8^{*}$ & $0.51 \pm 0.03^{*}$ & $1.11 \pm 0.07$ & $137.1 \pm 26.2^{*}$ & 5 \\
\hline$\alpha_{2} \beta_{3} \gamma_{2 \text { F77l }}$ & $1.65 \pm 0.13$ & $68.8 \pm 7.4^{*}$ & $0.36 \pm 0.02^{*}$ & $1.29 \pm 0.12$ & $174.4 \pm 28.7^{*}$ & 5 \\
\hline
\end{tabular}

GABA I $\max =1$; Responses to different taurine concentrations relative to I GABA max were fitted with a logistic Hill equation as shown in Fig. 1: $E C_{50}$, $\mathrm{nHill}$ and maximal efficacy (relative to GABA), obtained from this curve-fit analysis are provided for each receptor type. Exceptions are marked with $\sim$ (in these two cases, the curve-fit failed due to the large deviation from mean of experimental values. Mean relative response amplitude (to $0.6 \mathrm{M}$ taurine) is given). Values represent mean \pm SEM. n.p. $=$ not predictable. All values were compared to those seen in the corresponding binary $\left(\alpha_{x} \beta_{x}\right)$ receptor type (fat); significant difference is indicated $\left({ }^{*} p<0.05,{ }^{* *} p<0.01\right.$, non - parametrical Mann - Whitney U-test).

doi:10.1371/journal.pone.0061733.t001

[31]. Proper incorporation of $\gamma_{2 F 77 I}$ into $G_{A B A} R$ was verified by zinc-resistance (Figure $\mathrm{S} 1$ ). In all investigated receptor types taurine efficacy was significantly reduced at mutated compared to the corresponding wild type receptors: $\mathrm{p}<0.05$ for $\alpha_{1} \beta_{1} \gamma_{7 \mathrm{~F} 7 \mathrm{I}}$; $\mathrm{p}<0.01$ for $\alpha_{2} \beta_{1} \gamma_{2 \text { F77I }} ; \mathrm{p}<0.001$ for $\alpha_{2} \beta_{3} \gamma_{2 \text { F77I }}$ (Table 1, Fig. 2). As previous studies examining macroscopic (whole-cell currents) and microscopic (single-channel currents) kinetics of recombinant $\mathrm{GABA}_{\mathrm{A}} \mathrm{R}$ with a mutation within the GABA-binding site came to the conclusion that the reduction in agonist potency (e.g. a 70-fold increase in $\mathrm{EC}_{50}$ for GABA after mutation $\beta_{2}$-R207C) may be accompanied by the apparent reduction (by half) of the relative efficacy of a partial agonist (e.g. piperidine-4-sulfonic acid, P4S) under the slow, but not under the fast solution exchange conditions [40]. In order to control for this possibility we performed a correlation analysis between the relative potency of taurine $\left(\mathrm{EC}_{50}\right.$ taurine/ $\left.\mathrm{EC}_{50} \mathrm{GABA}\right)$ versus relative efficacy of taurine for all individual measurements from $\gamma_{7 \mathrm{~F} 77 \mathrm{I}}$-containing and corresponding WT receptors. There was no significant correlation (Pearson coefficient: $-0.07, \mathrm{p}=0.75$ ). Taurine was 

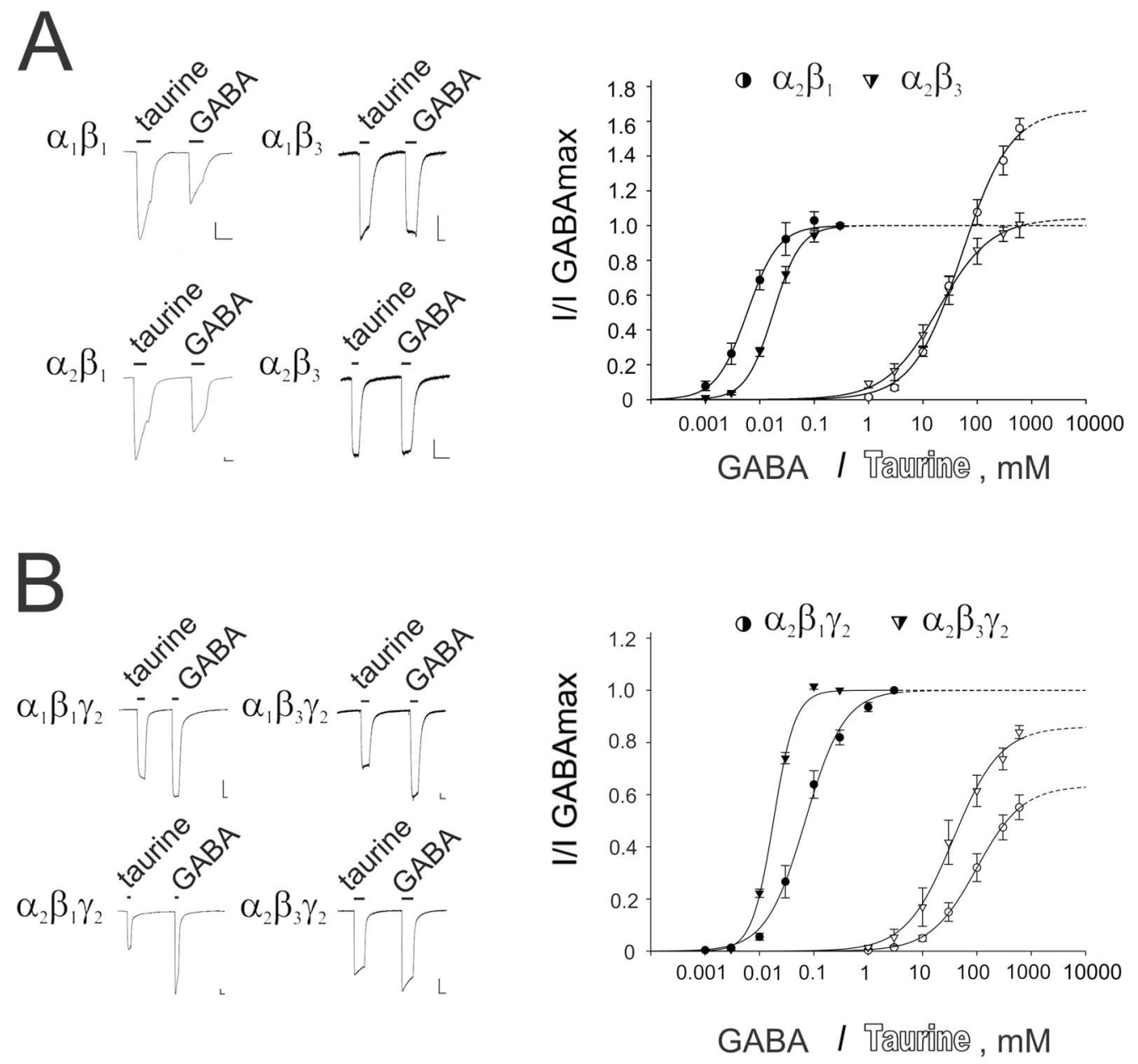

Figure 1. Comparison of taurine- and GABA-evoked maximal currents recorded from binary $\alpha_{x} \beta_{x}(A)$ or ternary $\alpha_{x} \beta_{x} \gamma_{2 L}(B)$ GABA receptors. Note that gating by taurine of $\gamma_{2}$ subunit containing $G A B A_{A}$ receptors is significantly less efficacious compared to the corresponding binary receptors. Representative current traces (comparison of taurine $(600 \mathrm{mM})$ - and GABA (0.1-1 mM) -evoked maximal currents at different receptor subtypes) are shown at the left. Scale markers represent $0.1 \mu \mathrm{A}$ vertically and $20 \mathrm{~s}$ horizontally for all figures with oocyte recordings. Right: averaged concentration - response curves. Concentration of agonist (filled symbols for GABA -, open symbols for taurine - responses) is plotted versus normalized response amplitudes. Each individual measurement was first normalized to the observed maximal GABA - current amplitude and subsequently averaged. Number of investigated oocytes, Hill coefficients (nHill) and concentrations evoking a half - maximal response (EC 50 ) are presented in Table 1.

doi:10.1371/journal.pone.0061733.g001

$1965 \pm 219$ times $(\mathrm{n}=15)$ and $1692 \pm 154$ times $(\mathrm{n}=11)$ less potent than GABA in KI and WT receptors, respectively $(\mathrm{p}=0.8)$, but its relative efficacy was significantly lower in $\mathrm{KI}$ receptors $(45.6 \pm 3.7 \%$ vs $74.6 \pm 3.7 \%$, respectively, $p=0.0002)$.

\section{$\mathrm{GABA}_{\mathrm{A}}$ Receptors in Zinc-resistant Neurons from Mutant $\gamma_{2 F 771}$ Mice show Reduced Taurine Gating}

Acutely isolated mouse TMN neurons responded to GABA with $\mathrm{EC}_{50} \mathrm{~s}$ around $15 \mu \mathrm{M}$. There was no difference in GABAsensitivity between $\gamma_{2 \text { F77I }}$ mice and their WT littermates. All data presented in the manuscript are obtained from neurons expressing histidine decarboxylase (cell identification with single-cell RTPCR). In contrast to the rat [25], where $\mathrm{GABA}_{\mathrm{A}} \mathrm{Rs}$ are "zincresistant" in all TMN neurons, about $30 \%$ of mouse TMN neurons are zinc-sensitive. No difference in the occurrence of zincsensitivity was found between $\gamma_{2 \text { F77I }}$ (knock-in, KI) mice and their WT littermates $(27.7 \%$ and $27 \%$ of cells, respectively). GABA $\mathrm{EC}_{15}$ responses were inhibited by $30 \mu \mathrm{M}$ of $\mathrm{ZnCl}_{2}$ in zinc-sensitive cells to $28.2 \pm 5.3 \%$ of control and by $10 \mu \mathrm{M}$ to $52.1 \pm 5.9 \%$ of control (pooled data from $3 \mathrm{WT}$ and $5 \mathrm{KI}$ neurons, where a complete analysis of $\mathrm{GABA}_{\mathrm{A}} \mathrm{R}$ expression with single-cell RTPCR was successfully done, Fig. 3). In zinc-resistant cells, where $10 \mu \mathrm{M}$ of zinc did not affect GABA-responses, inhibition by $30 \mu \mathrm{M}$ zinc amounted to $74.1 \pm 2.2 \%$ of control (significantly different from "zinc-sensitive" cells; $p<0.01$ ). The apparent macroscopic desensitization of current responses to saturating GABA concentration (plateau/peak ratio at the end of a $2 \mathrm{~s}^{-}$ application period) amounted to $73.3 \pm 3.3 \%(\mathrm{n}=5)$ vs $67.6 \pm 3.7 \%$ $(\mathrm{n}=10)$, in zinc-sensitive and zinc-resistant cells respectively (the difference is not significant). In $25 \%$ of the zinc-sensitive cells mRNAs encoding for $\gamma$ subunits were not detected, whereas in the same cells $\alpha$ - and $\beta$-subunit transcripts were present. Two different $\gamma$ subunits were never found coexpressed in zinc-sensitive neurons, whereas $48 \%$ of zinc-resistant cells coexpressed $\gamma_{1}$ and $\gamma_{2}$ subunits $(\mathrm{p}<0.05$, Fisher's test). All zinc-resistant cells $(\mathrm{n}=21)$ expressed either $\gamma_{1}(57 \%)$ or $\gamma_{2}(90.5 \%)$ subunit or both. The detection frequency of any of the $\mathrm{GABA}_{\mathrm{A}} \mathrm{R}$ subunits did not differ between $11 \mathrm{WT}$ and $18 \mathrm{KI}$ neurons (\% of positive cells: WT vs KI): $\alpha_{1}$ in 

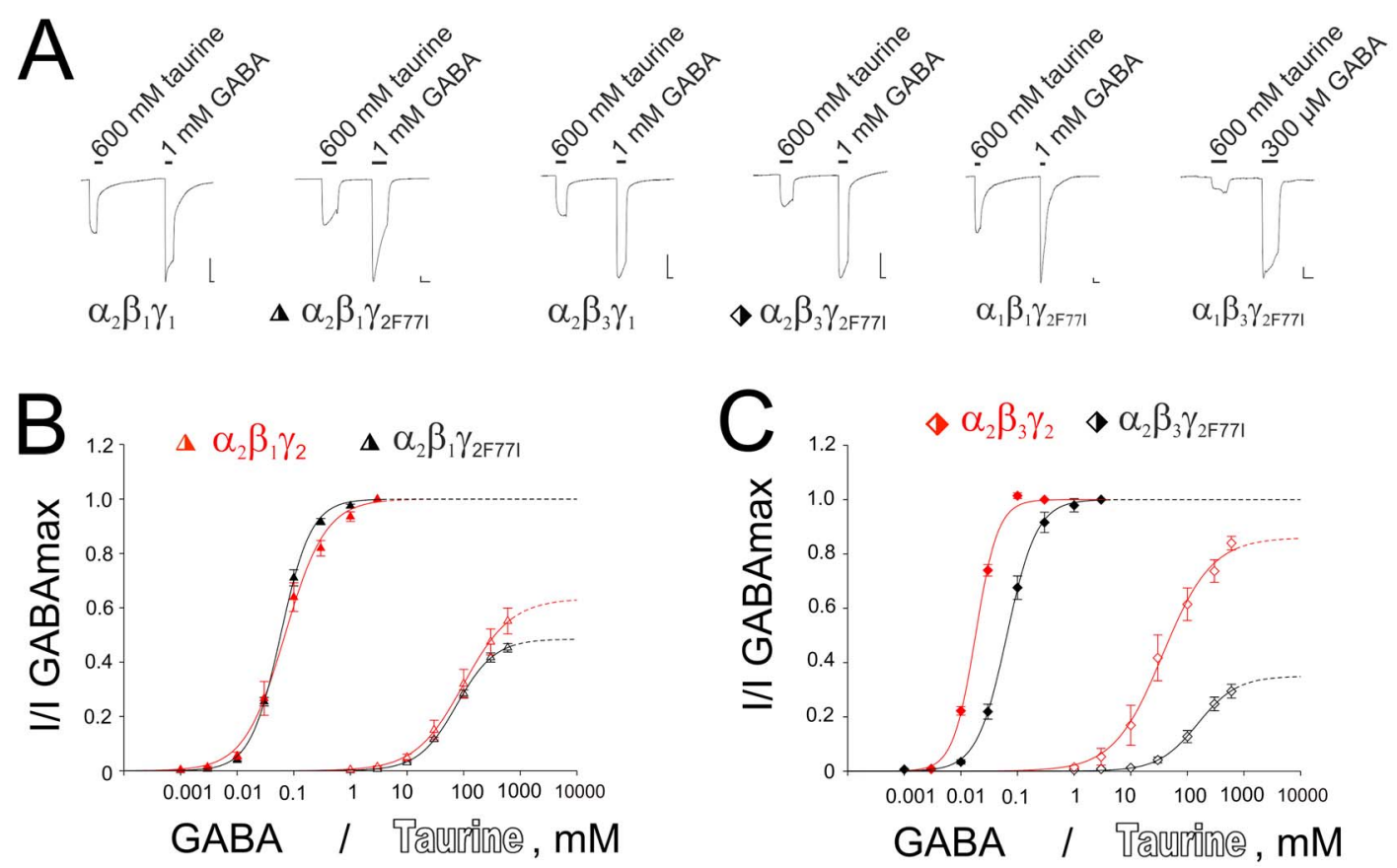

Figure 2. Mutation $\gamma_{2 F 771}$ reduces taurine efficacy at recombinant $\mathbf{G A B A}_{\mathbf{A}}$ receptors. (A) Representative current traces show responses to the maximal GABA and taurine concentrations at different receptor types. For two representative receptor types (marked with symbols) concentration-response plots for GABA (filled symbols) and taurine (open symbols) are shown in (B) and (C). Data obtained in corresponding wild type receptors $\left(\gamma_{2}\right.$ instead of $\left.\gamma_{2 F 771}\right)$ are plotted in red. doi:10.1371/journal.pone.0061733.g002

$18 \%$ vs $28 \%, \alpha_{2}$ in $100 \%$ vs $94 \%, \alpha_{5}$ in $18 \%$ vs $17 \%, \beta_{1}$ in $18 \%$ vs $44 \%, \beta_{2}$ in $9 \%$ vs $17 \%, \beta_{3}$ in $91 \%$ vs $78 \%, \gamma_{1}$ in $36 \%$ vs $50 \%$ and $\gamma_{2}$ in $82 \%$ vs $83 \%$. None of the cells expressed a detectable amount of $\gamma_{3}$ subunit transcripts. Semiquantitative real-time PCR analysis of $\gamma_{2}$ subunit expression revealed no difference in mRNA levels between TMN of $\gamma_{2 \text { F77I }}$ KI mice $(n=5)$ and their WT littermates $(\mathrm{n}=5): 1.5 \pm 0.1$ vs $1.5 \pm 0.2(\mathrm{p}=0.83)$. In WT mice taurine was more effective $(\mathrm{p}<0.05)$ in "zinc-sensitive" cells compared to "zinc-resistant" ones (Fig. 3B and C). In "zinc resistant cells" taurine was significantly more efficient in WT $(72 \pm 2.4 \%$ of maximal GABA-currents, $\mathrm{n}=10)$ compared to KI mice $(53 \pm 2 \%, \mathrm{n}=14$; Fig. $4 \mathrm{~A}$ and $\mathrm{B})$. Neither taurine potency $(13 \pm 1 \mathrm{mM}$ vs. $19.4 \pm 1.3 \mathrm{mM})$ nor slope functions of dose-response curves (nHill $1.7 \pm 2$ vs. 1.74 \pm 0.14 ) differed between WT and KI neurons. The GlyR-mediated component of taurine-responses was subtracted from each response-amplitude (remaining component after co-application of taurine and gabazine $20 \mu \mathrm{M}$, Fig. 4C).

\section{Super-agonistic Properties of Taurine at $\alpha_{x} \beta_{1} \delta$-receptors can be Transferred to the $\alpha_{x} \beta_{1} \gamma_{2 L}$ Receptors by Introducing into the $\gamma_{2 L}$ Subunit the $\delta$-motif: MTVFLH}

This and previous studies show that $\delta$-containing receptors are more potently and efficiently gated by taurine than $\gamma$-containing receptors. The molecular determinants for high sensitivity to taurine are unknown. We exchanged the $\gamma_{2}$ motif around phenylalanine 77 which we found to be responsible for the reduced efficacy of taurine with the corresponding motif of the $\delta$ subunit (Fig. 5). The resulting chimeric receptors $\alpha_{x} \beta_{1} \gamma_{2(\delta 74-79)}$ displayed superagonistic properties of taurine, which did not differ significantly from the $\alpha_{x} \beta_{1} \delta$ receptors (Table 1, Fig. 6). Interestingly, co-assembly of the chimeric $\gamma_{2}$ subunit with $\alpha_{\mathrm{x}}$ and $\beta_{3}$ subunits did not render taurine agonism superior to GABA (Table 1). Chimeric $\alpha_{2} \beta_{3} \gamma_{2(\delta 74-79)}$ receptors were insensitive to zolpidem, like $\alpha_{2} \beta_{3} \gamma_{2 \text { F77I }}$ or $\alpha_{2} \beta_{1} \gamma_{1}$ receptors (Figure S3). When GABA (at $\mathrm{EC}_{10}$ ) was co-applied with $1 \mu \mathrm{M}$ zolpidem, the resulting currents represented $97 \pm 7 \%$ of control $(n=5)$. At wild type $\alpha_{2} \beta_{3} \gamma_{2}$ receptors the same concentration of zolpidem increased control GABA-response to $430 \pm 70 \%$ of control $(n=5)$. Thus, zolpidem insensitivity could be transferred from $\delta$ to $\gamma_{2}$ through the motif MTVFLH.

\section{Discussion}

We demonstrate that taurine gating depends on the type of $\beta$ subunit and is negatively affected by the $\gamma$ subunit of the $\mathrm{GABA}_{\mathrm{A}} \mathrm{R}$. The mutation $\gamma_{2 \text { F77I }}$ which makes the $\mathrm{GABA}_{\mathrm{A}} \mathrm{R}$ zolpidem-insensitive reduces the efficacy of taurine-gating in recombinant and native $\mathrm{GABA}_{\mathrm{A}}$ receptors. Substitution of the $\gamma_{2}$ subunit motif around phenylalanine 77 (mouse $\gamma_{2}$ subunit numbering) with the corresponding $\delta$ subunit motif (MTVFLH) results in a receptor with superagonistic properties of taurine in $\beta_{1}$ but not in $\beta_{3^{-}}$containing receptors.

Our results obtained on recombinant $\mathrm{GABA}_{\mathrm{A}} \mathrm{R}$ expressed in Xenopus oocytes are in line with a previous report on decreased efficacy and potency of taurine at ternary $\alpha_{1} \beta_{3} \gamma_{2}$ receptors compared to binary $\alpha_{1} \beta_{3}$ receptors expressed in HEK293 cells [15]. This decrease in efficacy was accompanied by decreased taurine potency at $\alpha_{1} \beta_{3} \gamma_{2}$ and $\alpha_{2} \beta_{3} \gamma_{2}$ receptors (Table 1; present study and [15]). Interestingly, $\beta_{1}$-coassembly with the $\gamma_{2}$ subunit resulted in a reduction of taurine efficacy and potency in $\alpha_{2}$ - but an increased potency in $\alpha_{1}$-containing pentamers in our study. We are aware of the technical limitations in our measurements of maximal efficacies and potencies of $\mathrm{GABA}_{\mathrm{A}} \mathrm{R}$ agonists due to the slow speed of the solution exchange around an oocyte. Apparent efficacies and potencies were calculated from the peak responses which represent the sum of different processes such as fast kinetics of receptor activation and desensitization and the slow concen- 

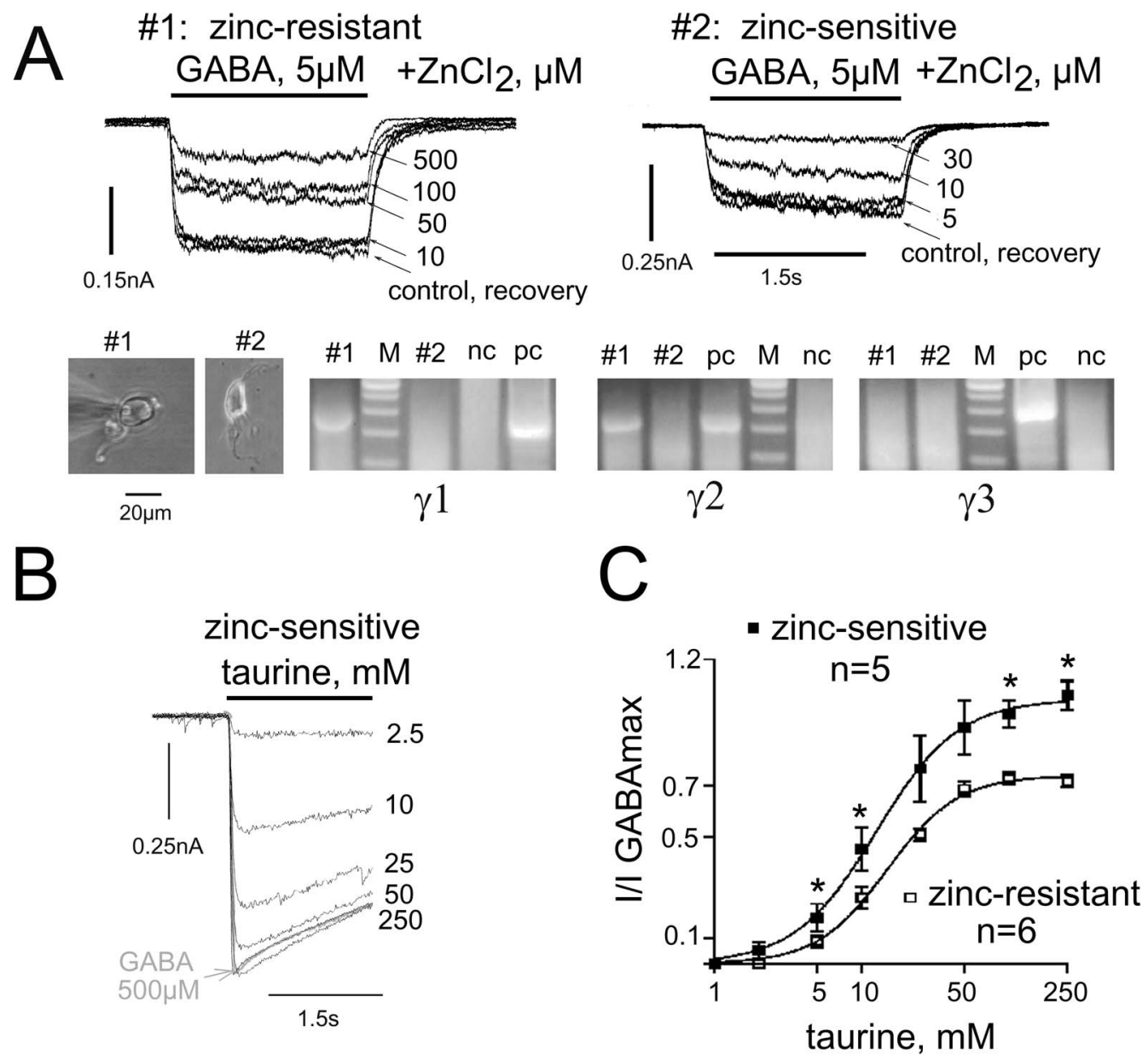

Figure 3. Zinc-sensitive TMN neurons show similar efficacies for GABA and taurine. (A) Zinc-inhibition of GABA-evoked currents in two representative neurons. Note that these neurons respond differently to $\mathrm{ZnCl}_{2} 10 \mu \mathrm{M}$. Block of the GABA-response by this concentration served as a criterion for the selection of "zinc-sensitive" neurons. (B) Photographs of two neurons and gels illustrating single-cell RT-PCR analysis of $\gamma$-subunit $(\gamma 1-\gamma 3)$ expression. Note the lack of a detectable amount of $\gamma$-subunit transcripts in zinc-sensitive cell (\#2). (C) Superimposed responses to different concentrations of taurine in comparison to the maximal GABA response recorded in one zinc-sensitive neuron. (D) Averaged concentration response plots for the two neuronal groups. Significant difference between individual data points is indicated: ${ }^{*}=p<0.05$. The maximal taurineevoked currents represented $100 \pm 5 \%$ (filled squares, $\mathrm{EC}_{50}=12.6 \pm 0.6 \mathrm{mM}, \mathrm{n}=5$ ) vs $74 \pm 2 \%$ (open squares, $\mathrm{EC}_{50}=14.9 \pm 0.9 \mathrm{mM}, \mathrm{n}=6$ ) of maximal GABA-evoked currents.

doi:10.1371/journal.pone.0061733.g003

tration ramp. Theoretical predictions formulated in a study by Wagner et al [40] are the following: i) the true maximal efficacy or open probability is underestimated in experiments on oocytes as desensitization during the agonist concentration ramp blunts the peak amplitude of the response; ii) the degree of this blunting depends on ligand affinity, such that high affinity ligands reach higher effective concentrations sooner during the agonist concentration ramp than do low affinity ligands. Although absolute efficacy and potency values can only be obtained from experiments recording single channel activity, our results from Xenopus oocytes are in line with those from HEK293 cells [15] and native neurons (present study) where a much faster solution exchange around smaller cells was achieved. Combining patch-clamp recordings from hypothalamic neurons with single-cell RT-PCR we observed the same structure-function relation for taurine gating of native $\mathrm{GABA}_{\mathrm{A}} \mathrm{R}$ as seen in Xenopus oocytes. Thirty percent of mouse histaminergic neurons expressed $\mathrm{GABA}_{\mathrm{A}} \mathrm{R}_{\mathrm{s}}$ with high zinc sensitivity indicating the prevalence of binary $\left(\alpha_{\mathrm{x}} \beta_{\mathrm{x}}\right)$ receptors over ternary $\left(\alpha_{x} \beta_{x} \gamma_{x}\right)$ in these cells. The functionality of such receptors was demonstrated by Gunther et al. [41] in $\gamma 2$ - subunit knockout mice. Taurine efficacy was comparable to GABA in zinc-sensitive cells, whereas taurine was less efficient than GABA in zincresistant cells, in keeping with the findings on recombinant $\gamma$ containing receptors expressed in Xenopus oocytes (Table 1), where taurine efficacy varied between $60-70 \%\left(\alpha_{1} \beta_{3} \gamma_{2}, \alpha_{2} \beta_{1} \gamma_{1}, \alpha_{2} \beta_{1} \gamma_{2}\right)$ and $80-90 \% \quad\left(\alpha_{1} \beta_{1} \gamma_{2}, \quad \alpha_{1} \beta_{2} \gamma_{2}, \quad \alpha_{2} \beta_{3} \gamma_{2}\right)$ of maximal GABAresponses. Note that in TMN neurons, which variably express 9 subunits of $\mathrm{GABA}_{\mathrm{A}} \mathrm{R}$ [27], all aforementioned $\mathrm{GABA}_{\mathrm{A}} \mathrm{R}$ types are likely occurring. The potency of taurine was not different between zinc-sensitive and zinc-resistant neurons, indicating that $\alpha_{1}$ - and $\alpha_{2}$-containing $\mathrm{GABA}_{\mathrm{A}} \mathrm{R}$-populations, which show different changes in taurine potency upon co-assembly with the $\gamma$ subunit (see above), may both contribute to the TMN pharmacology.

Receptors lacking a benzodiazepine (BZ) -binding site, such as $\alpha_{1 / 2} \beta_{1}$, and $\alpha_{1 / 2} \beta_{1} \delta$, are better gated by taurine than by GABA (Table 1, Fig. 1). Our observation that taurine gating of $\beta_{3^{-}}$ containing receptors with the same stoichiometry was weaker compared to $\beta_{1}$-containing receptors could be explained by the presence of a low - affinity binding site for BZ at $\beta_{2 / 3}$ but not at $\beta_{1}$ receptors [42]. The mutation $\gamma_{2 \text { F77I }}$ which abolished zolpidem - 

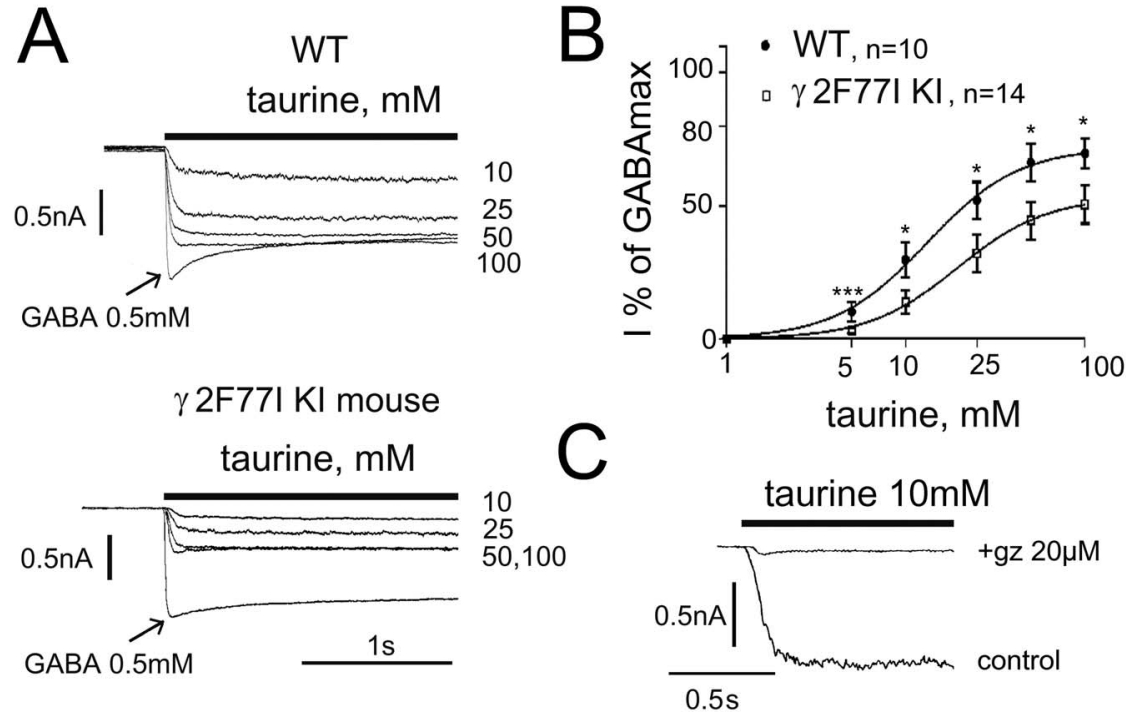

Figure 4. Gating of native $\mathbf{G A B A}_{\mathbf{A}}$ receptors by taurine is impaired by the mutation $\gamma_{\mathbf{2 F 7 7 1}}$ (A) Whole-cell voltage-clamp recordings $\left(V_{h}=-50 \mathrm{mV}\right.$ ) from adult WT or KI mouse TMN neurons isolated from hypothalamic slices. Taurine evokes maximal responses (at 50 and $100 \mathrm{mM}$ ) which are comparable in amplitude to the maximal GABA $(0.5 \mathrm{mM})$-evoked currents in wild-type (WT) mouse but represents only half of the GABAresponse in the knock-in (KI) $\gamma_{2 F 771}$ mouse. (B) Averaged concentration - response curves obtained from 10 WT and 14 KI neurons. Significant difference between individual data points is indicated: ${ }^{*} p<0.05$; ${ }^{* *} p<0.005$. (C) $G A B A_{A} R$ - versus GlyR-involvement in taurine-responses was tested by the co-application of taurine with gabazine ( $g z, G A B A_{A} R$ antagonist). Amplitude of the remaining response was subtracted in each neuron from the control taurine response, to construct the concentration - response curves in (B).

doi:10.1371/journal.pone.0061733.g004

potentiation did not rescue taurine gating. In contrast, taurine efficacy significantly dropped in this mutation, resembling now the taurine efficacy at the equivalent $\gamma_{1}$ - containing receptors, which are poorly potentiated by a variety of BZ - site ligands [39] and naturally carry isoleucine at the position 77 . We conclude that steric intersubunit - interactions (see below), rather than the BZ binding site per se, play a decisive role for taurine or GABA gating as well as for the modulatory action of BZ.

In line with the data obtained on recombinant receptors containing the mutant $\gamma_{2 \text { F77I }}$ subunit, taurine efficacy was reduced in zinc - resistant native neurons from $\mathrm{KI}\left(\gamma_{2 \mathrm{~F} 77 \mathrm{I}}\right)$ mice from $72 \%$ to $54 \%$ of maximal GABA efficacy. This efficacy drop corresponds very well to the values obtained from recombinant $\alpha_{2} \beta_{1} \gamma_{2}$ receptors $\left(70 \%\right.$ WT vs. $50 \%$ in $\left.\alpha_{2} \beta_{1} \gamma_{2 \text { F77I }}\right)$ and supports our previous conclusion that the $\alpha_{2} \beta_{1} \gamma_{2}$ receptor type plays a dominant role for the pharmacology of TMN neurons [27;28].

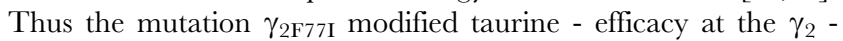
containing $\mathrm{GABA}_{\mathrm{A}} \mathrm{Rs}$. The (patho)physiological conditions for the gating of these receptors by taurine are unknown. The normal extracellular concentration of taurine is $>20$ times below their activation threshold. The expression of the $\alpha_{4}$ and $\delta$ subunits increases in the hippocampus of $\gamma_{2 \mathrm{~F} 77 \mathrm{I}} \mathrm{KI}$ mice, indicating that $\delta$ containing receptors might be up -regulated as compensatory response for the impaired taurine efficacy at $\gamma_{2}$ - containing receptors. This may be a reason for the lack of behavioural abnormalities in these mice compared to WT littermates [29;34].

\begin{tabular}{|c|c|}
\hline & 60 \\
\hline$A_{A} \delta$ & TVELHQSW \\
\hline & YVNS IGPVDPINMEYTIDI IFAQTWFDSRLKFI \\
\hline & YVNS IGPVNAINMEYTIDIFFAQTWY \\
\hline$\gamma_{2 \mathrm{~F} 771}$ & INMEYTIDIIFA \\
\hline & DMVSEVNMDYTLTMYFQQSWKDKRLSYSGI \\
\hline & SEVNMDYTLTMYFQQAWRDI \\
\hline & DMVSEVNMDYTLTMYFQQYWRDKRLA) \\
\hline & GPVSDHDMEYTIDVFFRQSWKDERLKE \\
\hline & תחס \\
\hline
\end{tabular}

Figure 5. Sequence alignment of $\mathrm{GABA}_{\mathrm{A}}$ receptor subunits between amino acids 58 and 92 ( $\gamma_{2}$ mouse numbering). Underlined is a putative assembly signal conserved in different $G_{A B A}$ receptor subunits (36)). Note no difference between all three $\beta$ - subunits in the putative assembly signal: MDYTLTMYFQQ_W with the exception for the position 81 (different residues are indicated in different colour). Interestingly, these coloured $\beta$ subunit-specific residues were shown previously to affect stabilization of a homomeric assembly (45). Fat letters show $\delta$ : MTVFLH and $\gamma_{2}$ : IDIFFA motifs which were exchanged in the chimeric $\gamma_{2(\delta 74-79)}$ subunit. Orange field indicates location of $\gamma_{2 F 77}$ site involved in zolpidem binding as well as homologous or same residues at other $\mathrm{GABA}_{A} \mathrm{R}$ subunits. doi:10.1371/journal.pone.0061733.g005 

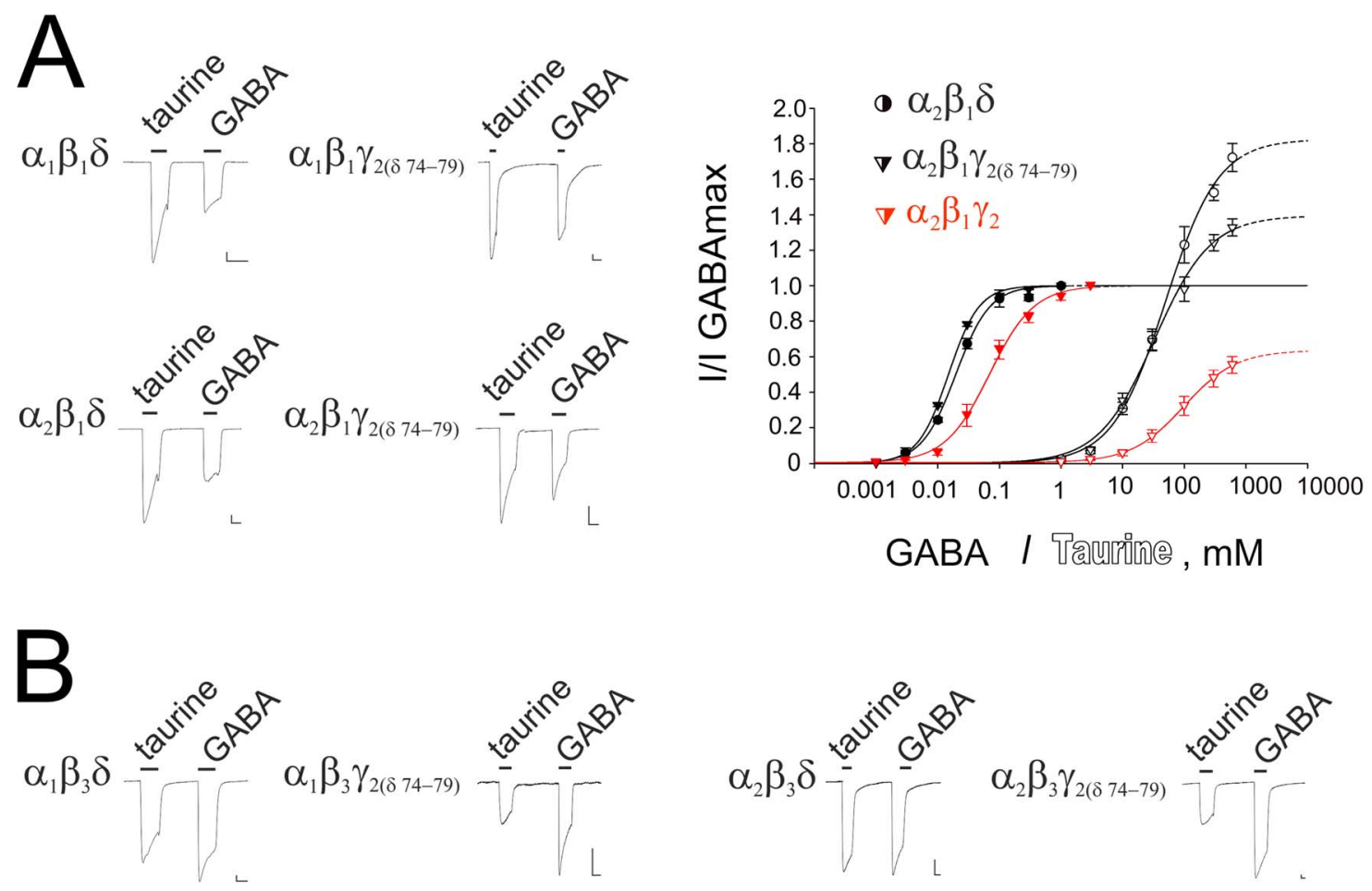

Figure 6. Chimeric $\alpha_{x} \beta_{1} \gamma_{2(\delta 74-79)}$ receptors show superagonistic properties of taurine. (A and B) Representative current traces (comparison of taurine $(600 \mathrm{mM})$ - and GABA $(0.3-3 \mathrm{mM})$ - evoked maximal currents) are shown for different receptor types. (A) Concentration response curves for the $\beta_{1}$-containing receptors. Concentrations of agonist are plotted versus current amplitudes normalized on maximal GABA response (filled symbols for GABA -, open symbols for taurine - responses). Red curves are given for comparison with $\gamma_{2}$ (WT) - containing receptors. Note the dramatic increase in taurine efficacy over GABA in chimeric $\beta_{1}$ - containing GABA $A_{A}$, which renders them similarity with the $\alpha_{2} \beta_{1} \delta$ receptors. doi:10.1371/journal.pone.0061733.g006

Jia et al. [11] reported that, at extrasynaptic receptors of the $\alpha_{4} \beta_{2} \delta$-type, taurine shows agonistic properties superior to GABA and controls the excitability of mouse ventrobasal thalamic neurons. Jia et al. found a big difference in taurine sensitivity between recombinant $\alpha_{4} \beta_{2} \delta$ receptors (threshold concentration $300 \mu \mathrm{M}, \mathrm{EC}_{50}=7.5 \mathrm{mM}$ ) and native extrasynaptic receptors of possibly the same subunit composition (threshold concentration $10 \mu \mathrm{M}$, potency is not determined). In our study taurine showed higher potency at neuronal receptors $\left(\mathrm{EC}_{50}=13-19 \mathrm{mM}\right) \mathrm{com}-$ pared to the corresponding recombinant $\alpha_{2} \beta_{1} \gamma_{2}$-receptors $\left(\mathrm{EC}_{50}=120 \mathrm{mM}\right)$ with threshold concentrations just above $1 \mathrm{mM}$. This disparity may result from the absence of $\mathrm{GABA}_{\mathrm{A}} \mathrm{R}$ - associated proteins or yet unknown intracellular modulators in recombinant systems [11]. The exceptionally high potency and efficacy of taurine at $\alpha_{4} \beta_{2} \delta$ receptors reported by Jia et al [11] together with the partial agonism of taurine at $\alpha_{6} \beta_{2} \delta$ receptors [16] support our observation that the type of $\alpha$ subunit influences taurine binding or the transduction to receptor gating. Neither $\alpha_{1} \beta_{\mathrm{x}} \delta$ nor $\alpha_{2} \beta_{\mathrm{x}} \delta$ receptors in our study showed higher sensitivities to GABA when compared to the corresponding $\alpha_{\mathrm{x}} \beta_{\mathrm{x}}$ receptors. This is in line with previous studies $[43 ; 44]$ where incorporation of the $\delta$ subunit was verified by concatenation. We applied tracazolate [35] at the end of each experiment to confirm the presence of a $\delta$ subunit in functional receptors. All data presented here are obtained from oocytes with different modulation of ternary versus binary receptors in parallel experiments. We cannot rule out the possibility of a sub-population of $\alpha_{\mathrm{x}} \beta_{\mathrm{x}}$ receptors along with $\alpha_{x} \beta_{x} \delta$, which we tried to prevent by injection of $10: 1: 10$ cRNA ratios. Furthermore, significantly different parameters derived from the agonist concentration - response relationship
(Table 1) indicates a prevalence of $\alpha_{x} \beta_{x} \delta$ receptor types. We compared taurine agonism between the restricted number of $\mathrm{GABA}_{\mathrm{A}} \mathrm{R}$ types expressed in histaminergic neurons and used $\delta$ containing receptors (which are not expressed in TMN) only for the comparison with chimeric receptors, composed of the $\gamma_{2}$ subunit with a $\delta$-motif (MTVFLH). Structural determinants for super- and partial- agonism of taurine at $\delta$-containing receptors await further characterisation.

The differences between $\beta_{1}$ and $\beta_{3}$ subunits seen in our study may rely on a number of subunit - specific residues involved in the stabilisation of receptor assembly. Bracamontes and Steinbach [45] described a number of $\beta_{3}$ - specific residues allowing the formation of functional homomultimeric receptors. Some of them are located near or within the assembly signal, e.g. tyrosine at the position 81 (see Fig. 5, present study). Others are at remote places and unlikely involved in gating or agonist binding; they may play a role in the stabilization of different receptor conformations. Steric intersubunit interactions in heteromeric $\beta_{1}$-containing receptors may support the stable transition from the closed to the open state after taurine binding at the $\alpha_{x} \beta_{1} \delta, \alpha_{x} \beta_{1} \gamma_{2(\delta 74-79)}$ and $\alpha_{x} \beta_{1}$ receptor, with taurine acting as a superagonist. In contrast, at $\beta_{3}$ - containing receptors taurine acts as a partial agonist compared to the analogous receptor types.

Our study reveals the importance of the $\gamma_{2}$ motif around phenylalanine 77 for the reduction of taurine efficacy at $\gamma$ containing receptors and shows that all three subunit types $(\alpha, \beta, \gamma)$ in the $\mathrm{GABA}_{\mathrm{A}}$ receptor can influence taurine agonism. Recent studies showed that the partiality of ligand agonism is pre determined by the earliest step of agonist binding [46;47]. According to models suggested by these studies, partial agonist- 
binding generates an unstable conformational change, leading to receptor-flipping between closed and opened states [46]. Thus, the difference between taurine - and GABA - gating of $\mathrm{GABA}_{\mathrm{A}} \mathrm{R}$ shown in this study indicates either a different but overlapping location of their binding sites or different transduction mechanisms at different receptor types.

By revealing structural demands for high efficacy $G_{A B A} R$ gating by taurine our study has broad physiological implications. Low taurine plasma level correlates with prediabetic and diabetic states and taurine supplementation is able to rescue insufficient insulin secretion by pancreatic islets [48]. Our data predict that a glucose-dependent up-regulation of the $\mathrm{GABA}_{\mathrm{A}} \mathrm{R} \gamma 2$-subunit in pancreatic islets can reduce taurine action [49] and increase the risk of diabetes. (Patho)physiological correlates of $\mathrm{GABA}_{\mathrm{A}} \mathrm{R}$ expression in pancreas await to be determined. Taurine deficiency in the brain results in GABAergic disinhibition, which models pathophysiological conditions of hepatic encephalopathy [12]. Thus the disclosure of structural demands for high efficacy taurine gating of $\mathrm{GABA}_{\mathrm{A}} \mathrm{R}$ provides the basis for future studies analysing the role of $\mathrm{GABA}_{\mathrm{A}} \mathrm{R}$ in diabetes mellitus and hepatic encephalopathy.

\section{Conclusions}

Our study provides new insight into molecular determinants of taurine gating at $\gamma$-subunit containing receptors. The mutation of phenylalanine to isoleucine at position 77 in the $\gamma_{2}$ subunit decreases, whereas introduction of the $\delta$ subunit-motif (MTVFLH) increases the efficacy of $\mathrm{GABA}_{\mathrm{A}} \mathrm{R}$ gating by taurine. We show, that $\beta_{1}$ (but not $\beta_{3}$ )-containing receptors display a wide range of taurine efficacies: from superagonism at $\alpha_{x} \beta_{1}$ or $\alpha_{x} \beta_{1} \delta$ receptors to partial agonism at $\gamma$-containing receptors. These findings shed light on the modification of $\mathrm{GABA}_{\mathrm{A}} \mathrm{R}$ under (patho)physiological conditions accompanying the loss of endogeneous taurine, such as diabetes mellitus or hepatic encephalopathy.

\section{Supporting Information}

Figure $S 1$ Zinc sensitivity of recombinant $\mathrm{GABA}_{\mathrm{A}}$ receptors. (A) Binary $\left(\alpha_{\mathrm{x}} \beta_{\mathrm{x}}\right.$, in black) $\mathrm{GABA}_{\mathrm{A}}$ receptors are inhibited by $1 \mu \mathrm{M}$ zinc, whereas ternary $\alpha_{\mathrm{x}} \beta_{\mathrm{x}} \gamma_{2}$ (dark grey) receptors are insensitive to zinc. Delta-containing $\alpha_{\mathrm{x}} \beta_{\mathrm{x}} \delta$ receptors (in white) do not differ in zinc-sensitivity from the corresponding $\alpha_{\mathrm{x}} \beta_{\mathrm{x}}$ receptors. Note that the zinc sensitivity is increased for $\alpha \beta \gamma_{2(\delta 74-79)}$ (light grey) receptors compared to the $\alpha_{\mathrm{x}} \beta_{\mathrm{x}} \gamma_{2 \text { F77I }}$ receptors. Values represent mean \pm SEM, $\mathrm{p}$ values are indicated by asterisk. * $<0.05, * *<0.01$, n.s. $=$ not significant. $(\mathbf{B})$ Representative current

\section{References}

1. Chepkova AN, Doreulee N, Yanovsky Y, Mukhopadhyay D, Haas HL, et al. (2002) Long-lasting enhancement of corticostriatal neurotransmission by taurine. Eur J Neurosci 16: 1523-1530.

2. Chepkova AN, Sergeeva OA, Haas HL (2006) Taurine rescues hippocampal long-term potentiation from ammonia-induced impairment. Neurobiol Dis 23: $512-521$.

3. Huxtable RJ (1992) Physiological actions of taurine. Physiol Rev 72: 101-163.

4. Sergeeva OA, Chepkova AN, Doreulee N, Eriksson KS, Poelchen W, et al.(2003) Taurine-induced long-lasting enhancement of synaptic transmission in mice: role of transporters. J Physiol 550: 911-919.

5. Gundersen V, Chaudhry FA, Bjaalie JG, Fonnum F, Ottersen OP, et al. (1998) Synaptic vesicular localization and exocytosis of L-aspartate in excitatory nerve terminals: a quantitative immunogold analysis in rat hippocampus. J Neurosci 18(16): 6059-6070.

6. Kontro P, Marnela KM, Oja SS (1980) Free amino acids in the synaptosome and synaptic vesicle fractions of different bovine brain areas. Brain Res 184: 129-141.

7. Molchanova S, Oja SS, Saransaari P (2004) Characteristics of basal taurine release in the rat striatum measured by microdialysis. Amino Acids 27: 261-268. traces from oocyte recordings. Application is marked by horizontal bars. Scale markers represent $0.1 \mu \mathrm{A}$ vertically and $20 \mathrm{~s}$ horizontally.

(PDF)

Figure S2 Tracazolate $(10 \mu \mathrm{M})$-potentiation of GABAevoked currents is different between ternary $\delta$-containing and corresponding binary $\alpha_{x} \beta_{x} G A B A_{A} R$ types if GABA at $\sim \mathbf{E G}_{10}$ (for the $\beta_{1^{-}}$) and at $\sim \mathbf{E G}_{99}$ (for the $\beta_{3^{-}}$ containing receptors) is used. (A) When GABA concentration around $\mathrm{EC}_{10}$ is used, tracazolate-potentiation of binary $\alpha_{\mathrm{x}} \beta_{1}$ (but not $\alpha_{x} \beta_{3}$ ) receptors is significantly smaller compared to the ternary $\delta$-containing receptors. (B) When the same experiments were done at saturating GABA concentrations $\left(\sim \mathrm{EC}_{99}\right)$ ternary $\alpha_{\mathrm{x}} \beta_{3} \delta-\mathrm{GABA}_{\mathrm{A}}$ receptors were potentiated to a larger extent than the corresponding binary receptors. Note no difference between $\beta_{1}$-containing ternary and binary receptors in experiments with this GABA concentration. $\mathrm{p}$ values are indicated by asterisk. * $<0.05, * *<0.01, * * *<0.001$, n.s. $=$ not significant.

(PDF)

Figure S3 Zolpidem potentiation of different GABA receptor types. (A) Zolpidem modulation of chimeric $\alpha_{2} \beta_{3} \gamma_{2(\delta}$ 74-79) $\mathrm{GABA}_{\mathrm{A}} \mathrm{Rs}$. Introduction of the $\delta$ 74-79 motif MTVFLH into the $\gamma_{2}$ subunit resulted in loss of potentiation by zolpidem, compared to the WT shown in (B). (B) Comparison of zolpidempotentiation between $\alpha_{2} \beta_{3} \gamma_{2}, \alpha_{2} \beta_{1} \gamma_{2}, \alpha_{2} \beta_{1} \gamma_{1}$ and $\alpha_{2} \beta_{3} \gamma_{2 \text { F77I }}$ receptors. Note much larger bi-phasic potentiation by zolpidem at $\beta_{3}$-containing receptors (in contrast to the $\beta_{1}$-containing receptors) in accordance with involvement of the low - affinity binding site for $\mathrm{BZ}$ at $\beta_{3}$ but not at $\beta_{1}$ receptors (44). This site is most likely responsible for the potentiation of GABA - responses at "zolpidem-resistant" ( $\gamma_{\left.2 \mathrm{~F} 77 \mathrm{I}^{-c o n t a i n i n g}\right)}$ receptors by $100 \mu \mathrm{M}$ zolpidem. Data represent mean \pm SEM of at least 4 individual oocytes.

(PDF)

\section{Acknowledgments}

We wish to thank W. Wisden (Imperial College London, UK) for the generous donation of $\gamma 2$ F77I mice.

\section{Author Contributions}

Conceived and designed the experiments: OAS OK GG HH. Performed the experiments: OK OAS GG AM. Analyzed the data: OK OAS GG AM. Contributed reagents/materials/analysis tools: OAS HH. Wrote the paper: OAS OK GG HH AM.

8. Albrecht J, Schousboe A (2005) Taurine interaction with neurotransmitter receptors in the CNS: an update. Neurochem Res 30: 1615-1621.

9. Lerma J, Herranz AS, Herreras O, Abraira V, Martin del RR (1986) In vivo determination of extracellular concentration of amino acids in the rat hippocampus. A method based on brain dialysis and computerized analysis. Brain Res 384: 145-155.

10. Liu QR, Lopez-Corcuera B, Nelson H, Mandiyan S, Nelson N (1992) Cloning and expression of a cDNA encoding the transporter of taurine and beta-alanine in mouse brain. Proc Natl Acad Sci U S A 89: 12145-12149.

11. Jia F, Yue M, Chandra D, Keramidas A, Goldstein PA, et al. (2008) Taurine is a potent activator of extrasynaptic GABA(A) receptors in the thalamus. J Neurosci 28: $106-115$.

12. Sergeeva OA, Fleischer W, Chepkova AN, Warskulat U, Haussinger D, et al. (2007) GABAA-receptor modification in taurine transporter knockout mice causes striatal disinhibition. J Physiol 585: 539-548.

13. Schmieden V, Kuhse J, Betz H (1992) Agonist pharmacology of neonatal and adult glycine receptor alpha subunits: identification of amino acid residues involved in taurine activation. EMBO J 11: 2025-2032. 
14. Sergeeva OA, Haas HL (2001) Expression and function of glycine receptors in striatal cholinergic interneurons from rat and mouse. Neuroscience 104: 10431055.

15. Dominguez-Perrot C, Feltz P, Poulter MO (1996) Recombinant GABAA receptor desensitization: the role of the gamma 2 subunit and its physiological significance. J Physiol 497: 145-159.

16. Hadley SH, Amin J (2007) Rat alpha6beta2delta GABAA receptors exhibit two distinct and separable agonist affinities. J Physiol 581: 1001-1018.

17. Olsen RW, Sieghart W (2009) GABA A receptors: subtypes provide diversity of function and pharmacology. Neuropharmacology 56: 141-148.

18. Baumann SW, Baur R, Sigel E (2002) Forced subunit assembly in alphalbeta2gamma2 GABAA receptors. Insight into the absolute arrangement. J Biol Chem 277: 46020-46025.

19. Farrant M, Nusser Z (2005) Variations on an inhibitory theme: phasic and tonic activation of GABA(A) receptors. Nat Rev Neurosci 6: 215-229.

20. Sigel E, Buhr A (1997) The benzodiazepine binding site of GABAA receptors. Trends Pharmacol Sci 18: 425-429.

21. Downing SS, Lee YT, Farb DH, Gibbs TT (2005) Benzodiazepine modulation of partial agonist efficacy and spontaneously active GABA(A) receptors supports an allosteric model of modulation. Br J Pharmacol 145: 894-906.

22. Ju YH, Guzzo A, Chiu MW, Taylor P, Moran MF, et al. (2009) Distinct properties of murine alpha 5 gamma-aminobutyric acid type a receptors revealed by biochemical fractionation and mass spectroscopy. J Neurosci Res 87 : 1737-1747.

23. McKernan RM, Whiting PJ (1996) Which GABAA-receptor subtypes really occur in the brain? Trends Neurosci 19: 139-143.

24. Nutt D (2006) GABAA receptors: subtypes, regional distribution, and function. J Clin Sleep Med 2: S7-11.

25. Sergeeva OA, Eriksson KS, Sharonova IN, Vorobjev VS, Haas HL (2002) GABA(A) receptor heterogeneity in histaminergic neurons. Eur J Neurosci 16: $1472-1482$.

26. Sergeeva OA, Andreeva N, Garret M, Scherer A, Haas HL (2005) Pharmacological properties of GABAA receptors in rat hypothalamic neurons expressing the epsilon-subunit. J Neurosci 25: 88-95.

27. Sergeeva OA, Kletke O, Kragler A, Poppek A, Fleischer W, et al. (2010) Fragrant dioxane derivatives identify betal-subunit-containing GABAA receptors. J Biol Chem 285: 23985-23993.

28. Yanovsky Y, Schubring S, Fleischer W, Gisselmann G, Zhu XR, et al. (2011) $\mathrm{GABA}(\mathrm{A})$ receptors involved in sleep and anaesthesia: beta1- versus beta3containing assemblies. Pflugers Arch. 463: 187-199.

29. Cope DW, Halbsguth C, Karayannis T, Wulff P, Ferraguti F, et al. (2005) Loss of zolpidem efficacy in the hippocampus of mice with the GABAA receptor gamma2 F77I point mutation. Eur J Neurosci 21: 3002-3016.

30. Schubring SR, Fleischer W, Lin JS, Haas HL, Sergeeva OA (2012) The bile steroid chenodeoxycholate is a potent antagonist at NMDA and GABA(A) receptors. Neurosci Lett 506: 322-326.

31. Ho SN, Hunt HD, Horton RM, Pullen JK, Pease LR (1989) Site-directed mutagenesis by overlap extension using the polymerase chain reaction. Gene 77 : 51-59.

32. Saras A, Gisselmann G, Vogt-Eisele AK, Erlkamp KS, Kletke O, et al. (2008) Histamine action on vertebrate GABAA receptors: direct channel gating and potentiation of GABA responses. J Biol Chem 283: 10470-10475.
33. Draguhn A, Verdorn TA, Ewert M, Seeburg PH, Sakmann B (1990) Functional and molecular distinction between recombinant rat GABAA receptor subtypes by Zn2+. Neuron 5: 781-788.

34. Nagaya N, Macdonald RL (2001) Two gamma2L subunit domains confer low Zn2+ sensitivity to ternary GABA(A) receptors. J Physiol 532: 17-30.

35. Thompson SA, Wingrove PB, Connelly L, Whiting PJ, Wafford KA (2002) Tracazolate reveals a novel type of allosteric interaction with recombinant gamma-aminobutyric acid(A) receptors. Mol Pharmacol 61: 861-869.

36. Bollan K, King D, Robertson LA, Brown K, Taylor PM, et al (2003) GABA(A) receptor composition is determined by distinct assembly signals within alpha and beta subunits. J Biol Chem 278: 4747-4755.

37. Kreienkamp HJ, Maeda RK, Sine SM, Taylor P (1995) Intersubunit contacts governing assembly of the mammalian nicotinic acetylcholine receptor. Neuron 14: 635-644.

38. Taylor PM, Connolly CN, Kittler JT, Gorrie GH, Hosie A, et al. (2000) Identification of residues within $\mathrm{GABA}(\mathrm{A})$ receptor alpha subunits that mediate specific assembly with receptor beta subunits. J Neurosci 20: 1297-1306.

39. Wingrove PB, Thompson SA, Wafford KA, Whiting PJ (1997) Key amino acids in the gamma subunit of the gamma-aminobutyric acidA receptor that determine ligand binding and modulation at the benzodiazepine site. Mol Pharmacol 52: 874-881.

40. Wagner DA, Czajkowski C, Jones MV (2004) An arginine involved in GABA binding and unbinding but not gating of the GABA(A) receptor. J Neurosci 24 : 2733-2741

41. Gunther U, Benson J, Benke D, Fritschy JM, Reyes G, et al. (1995) Benzodiazepine-insensitive mice generated by targeted disruption of the gamma 2 subunit gene of gamma-aminobutyric acid type A receptors. Proc Natl Acad Sci U S A 92: 7749-7753.

42. Walters RJ, Hadley SH, Morris KD, Amin J (2000) Benzodiazepines act on GABAA receptors via two distinct and separable mechanisms. Nat Neurosci 3: 1274-1281.

43. Baur R, Kaur KH, Sigel E (2010) Diversity of structure and function of alphalalpha6beta3delta GABAA receptors: comparison with alphalbeta3delta and alpha6beta3delta receptors. J Biol Chem 285(23): 17398-17405.

44. Kaur KH, Baur R, Sigel E (2009) Unanticipated structural and functional properties of delta-subunit-containing GABAA receptors. J Biol Chem 20;284(12): 7889-7896.

45. Bracamontes JR, Steinbach JH (2008) Multiple modes for conferring surface expression of homomeric betal GABAA receptors. J Biol Chem 19;283: 2612826136.

46. Lape R, Colquhoun D, Sivilotti LG (2008) On the nature of partial agonism in the nicotinic receptor superfamily. Nature 454: 722-727.

47. Mukhtasimova N, Lee WY, Wang HL, Sine SM (2009) Detection and trapping of intermediate states priming nicotinic receptor channel opening. Nature 459: 451-454.

48. Ribeiro RA, Bonfleur ML, Amaral AG, Vanzela EC, Rocco SA, et al. (2009) Taurine supplementation enhances nutrient-induced insulin secretion in pancreatic mice islets. Diabetes Metab Res Rev 25: 370-379.

49. Bailey SJ, Ravier MA, Rutter GA (2007) Glucose-dependent regulation of gamma-aminobutyric acid (GABA A) receptor expression in mouse pancreatic islet alpha-cells. Diabetes 56: 320-327. 